Article

\title{
Highly Efficient and Visible Light Responsive Heterojunction Composites as Dual Photoelectrodes for Photocatalytic Fuel Cell
}

\author{
Honghui Pan ${ }^{1}$, Wenjuan Liao ${ }^{1}$, Na Sun ${ }^{1}$, Muthu Murugananthan ${ }^{2}{ }^{(D)}$ and Yanrong Zhang ${ }^{1, *}$ \\ 1 Environmental Science Research Institute, Huazhong University of Science and Technology, \\ Wuhan 430074, China; honghui_pan@hust.edu.cn (H.P.); liaowenjuan@hust.edu.cn (W.L.); \\ nasun.hust@gmail.com (N.S.) \\ 2 Department of Chemistry, PSG College of Technology, Peelamedu, Coimbatore 641004, India; \\ muruga.chem@gmail.com \\ * Correspondence: yanrong_zhang@hust.edu.cn; Tel.: +86-027-877-9210-7802
}

Received: 11 November 2017; Accepted: 8 January 2018; Published: 18 January 2018

\begin{abstract}
In the present work, a novel photocatalytic fuel cell (PFC) system involving a dual heterojunction photoelectrodes, viz. polyaniline $/ \mathrm{TiO}_{2}$ nanotubes $\left(\mathrm{PANI} / \mathrm{TiO}_{2} \mathrm{NTs}\right.$ ) photoanode and $\mathrm{CuO} / \mathrm{Co}_{3} \mathrm{O}_{4}$ nanorods $\left(\mathrm{CuO} / \mathrm{Co}_{3} \mathrm{O}_{4} \mathrm{NRs}\right)$ photocathode, has been designed. Compared to $\mathrm{TiO}_{2}$ NTs electrode of PFC, the present heterojunction design not only enhances the visible light absorption but also offers the higher efficiency in degrading Rhodamine B-a model organic pollutant. The study includes an evaluation of the dual performance of the photoelectrodes as well. Under visible-light irradiation of $3 \mathrm{~mW} \mathrm{~cm}{ }^{-2}$, the cell composed of the photoanode $\mathrm{PANI} / \mathrm{TiO}_{2} \mathrm{NTs}$ and $\mathrm{CuO} / \mathrm{Co}_{3} \mathrm{O}_{4}$ NRs photocathode forms an interior bias of $+0.24 \mathrm{~V}$ within the PFC system. This interior bias facilitated the transfer of electrons from the photoanode to photocathode across the external circuit and combined with the holes generated therein along with a simultaneous power production. In this manner, the separation of electron/hole pair was achieved in the photoelectrodes by releasing the holes and electrons of $\mathrm{PANI} / \mathrm{TiO}_{2} \mathrm{NTs}$ photoanode and $\mathrm{CuO} / \mathrm{Co}_{3} \mathrm{O}_{4}$ NRs photocathode, respectively. Using this PFC system, the degradation of Rhodamine B in aqueous media was achieved to an extent of $68.5 \%$ within a reaction duration of a four-hour period besides a simultaneous power generation of $85 \mu \mathrm{A} \mathrm{cm}^{-2}$.
\end{abstract}

Keywords: polyaniline; titanium dioxide; copper(II) oxide; cobalt oxide(II,III); photocatalytic fuel cell

\section{Introduction}

Water pollution, a serious issue of global concern, is no doubt a grave threat to human health and societal progress. The contamination of natural water systems is mainly due to lack of effective and viable techniques and excessive discharge of wastewater containing toxic organic contaminants. Developing an effective purification technique to maintain a green ecological environment and simultaneously recover the chemical energy stored abundantly in toxic organics that usually let out as wastewater has become an urgent need of the hour [1-3]. A novel device, the so-called photocatalytic fuel cell (PFC), constituted with a photoanode and a photocathode, for wastewater treatment along with simultaneous electricity generation under solar irradiation, is an emerging and attractive technique in the energy and environmental domain [4-6]. In this system, the electron/hole pairs can be generated from the photoelectrodes under light irradiation in a defined wavelength region. The electrons produced from the photoanode leave the holes and transfer through the external circuit to the photocathode, and the holes at the photoanode are released for degradation of organic compounds [7]. In addition, the PFC system, in which an n-type semiconductor generally used as 
photoanode with a Fermi level higher than that of the cathode, could develop interior bias which facilitates the transfer of electrons from photoanode to photocathode thereby producing a concurrent generation of electricity [8]. The existing PFC systems constituting $\mathrm{TiO}_{2}$ and $\mathrm{Pt}$ as photoelectrodes $[3,8]$ have severe limitations because $\mathrm{TiO}_{2}$ responds most to ultraviolet (UV) region light and suffers from the high probability of electron/hole pair recombination [9]. Using Pt as photocathode is obviously not a viable approach, which would eventually restrict its application to a large-scale level [10].

To overcome the above mentioned drawbacks, the studies on either developing visible light responsive photoanodes [11-14] or replacing Pt by p-type semiconductor as the photocathode $[15,16]$ become equally important, leading to the development of dual photoelectrodes for PFC system. However, so far, these PFCs have been identified with its shortcomings that the photoactivity and photostability of the electrodes are poor, which limits their application. For instance, the visible-light driven PFC system using $\mathrm{CdS} / \mathrm{TiO}_{2}$ or $\mathrm{WO}_{3} / \mathrm{W}$ as photoanode and $\mathrm{Cu}_{2} \mathrm{O} / \mathrm{Cu}$ as photocathode suffers from poor stability of the $\mathrm{CdS}, \mathrm{WO}_{3}$ and $\mathrm{Cu}_{2} \mathrm{O}$ due to their photocorrosion nature in aqueous media [17]. The limited usage of these electrodes could be attributed largely to the inherent drawbacks of the material that result in poor response in visible-light region, weak stability and undesirable photoactivity, which eventually limit the performance of the PFC system.

Forming a heterojunction by two different semconductors is an effective strategy to facilitate the hole/electron seperation and enhance the photocatalytic activity $[18,19]$. For instance, polyaniline (PANI), a conducting polymer, might be a good choice for $\mathrm{TiO}_{2}$ sensitization [20] due to high absorption coefficients in the visible-light region, high mobility of charge carriers and good environmental stability. PANI $/ \mathrm{TiO}_{2}$ nanocomposite could be obtained by mixing commercial $\mathrm{TiO}_{2}$ nanopowder with PANI by a chemical oxidative polymerization step [20,21]. On the other hand, oxides of copper and cobalt, which are well known for their p-type semiconducting behavior, could be used as photocathode [22-24] replacing the noble metals and also as photocatalysts for degradation of pollutants [25]. These materials can withstand in the multiple processing steps and have a compatibility nature with other material systems. All these notable characteristics behavior make them attractive and interesting base materials for heterostructures. Chopra et al. $[25,26]$ recently established a fact that $\mathrm{CuO}$ nanowire $-\mathrm{Co}_{3} \mathrm{O}_{4}$ nanoparticle heterostructure has shown a unique photoactivity under visible-light irradiation. The $\mathrm{p}-\mathrm{p}$ junctions formed by the combination of $\mathrm{CuO}$ and $\mathrm{Co}_{3} \mathrm{O}_{4}$ could efficiently reduce the probability of recombination of photogenerated electron/hole pairs, which in turn enhances the photocatalytic activity.

In this work, a pair of materials, viz. $\mathrm{PANI} / \mathrm{TiO}_{2}$ nanotubes (NTs) as photoanode and $\mathrm{CuO} / \mathrm{Co}_{3} \mathrm{O}_{4}$ nanoparticles (NRs) as photocathode fabricated based on Ti substrate, was proposed as a novel PFC system, which exhibits an effective degradation behavior toward Rhodamine B and shows an efficient generation of electricity.

\section{Results and Discussion}

\subsection{Characterization of $\mathrm{PANI} / \mathrm{TiO} \mathrm{O}_{2}$ NTs Photoanode}

The microstructure and elements distribution of $\mathrm{TiO}_{2}$ and $\mathrm{PANI} / \mathrm{TiO}_{2} \mathrm{NTs}$ were studied by using Scanning Electron Microscope (SEM) and Energy Dispersive Spectrometer (EDX) (Figure 1), respectively. The $\mathrm{TiO}_{2}$ nanotube arrays were covered by a layer of discretely adhered PANI. As seen in the inset (Figure 1a), the cross-sectional view of $\mathrm{TiO}_{2}$ nanotube arrays substrate clearly displays the vertically oriented nanotubes with a length of about $900 \mathrm{~nm}$ and a wall thickness of $10 \mathrm{~nm}$. Additionally, from the EDX analysis, the existence of elements, viz. C, N, Ti and O, was confirmed and especially the minimum quantity of PANI with respect to the content of $\mathrm{TiO}_{2}$ substrate material was confirmed by the relatively low intensities observed against the elements $\mathrm{C}$ and N. Figure 2 shows the X-ray diffraction patterns (XRD) recorded for both $\mathrm{TiO}_{2}$ and $\mathrm{PANI} / \mathrm{TiO}_{2} \mathrm{NTs}$ materials. The peaks presented for $\mathrm{PANI} / \mathrm{TiO}_{2} \mathrm{NTs}$ reflect characteristics of anatase $\mathrm{TiO}_{2}$ and the predominant peak of $2 \theta$ at $25.2^{\circ}$ indicates a fine preferential growth of the Titania nanotube (TNTs) in 101 orientation 
(JCPDS no. 21-1272). The fact that no diffraction peak was observed for PANI might be due to its amorphous phase in the composite. The position and shape of the peaks observed in XRD patterns for PANI/ $\mathrm{TiO}_{2}$ NTs were almost identical with that of $\mathrm{TiO}_{2}$, indicate that the incorporation of PANI has no influence in the lattice structure of $\mathrm{TiO}_{2}$, which would be an added advantage for the hybrid photocatalytic material.
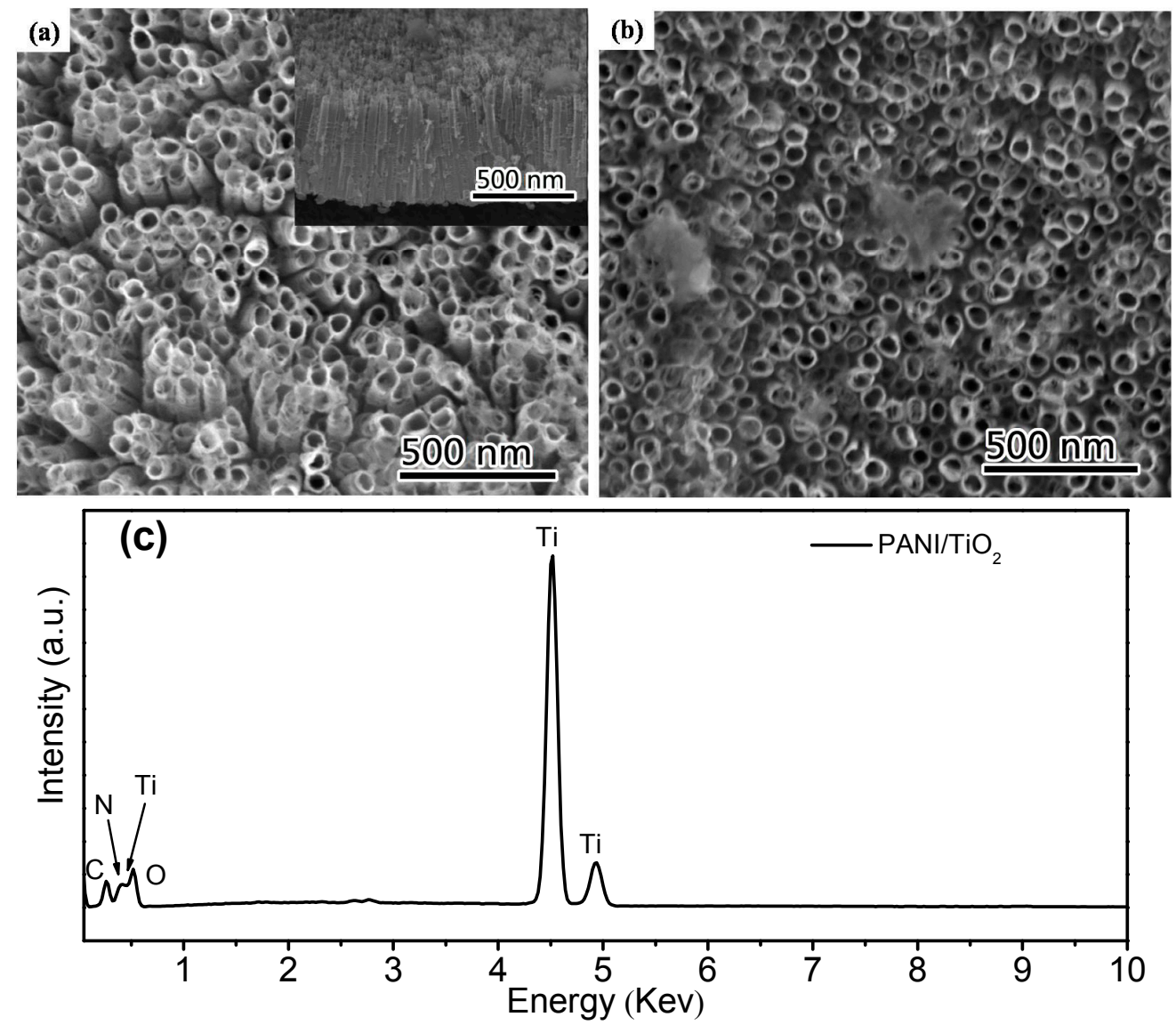

Figure 1. (a) $\mathrm{SEM}$ image of the $\mathrm{TiO}_{2}$ (the inset shows the cross-sectional image) and (b) polyaniline (PANI) $/ \mathrm{TiO}_{2}$ nanotubes (NTs), (c) EDX analysis of (b).

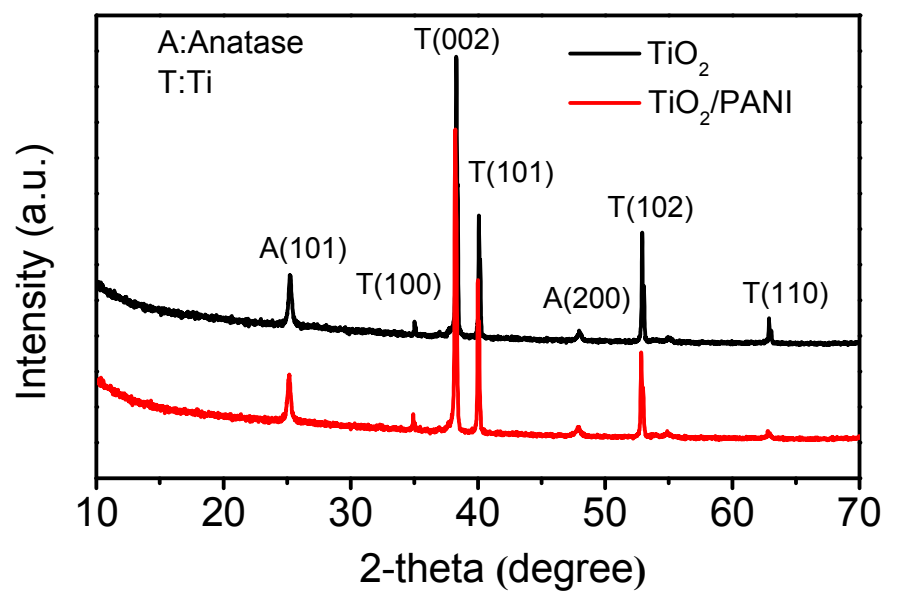

Figure 2. XRD patterns recorded for $\mathrm{TiO}_{2}$, and $\mathrm{PANI} / \mathrm{TiO}_{2} \mathrm{NTs}$. 
Figure 3 shows the Fourier Transform Infrared Spectroscopy (FTIR) spectra recorded for $\mathrm{TiO}_{2}$ and PANI $/ \mathrm{TiO}_{2}$ NTs as well. The wide peak observed at $500-800 \mathrm{~cm}^{-1}$ for $\mathrm{TiO}_{2}$ could be ascribed to the Ti-O bending mode of $\mathrm{TiO}_{2}$ sample. The strong characteristic absorption bands observed for PANI/TiO ${ }_{2}$ NTs, between 1200 and $1600 \mathrm{~cm}^{-1}$, were 1566, 1487, 1299, 1245 and $1127 \mathrm{~cm}^{-1}$. The bands at 1566 and $1487 \mathrm{~cm}^{-1}$ could be correlated to $C-C$ stretching mode of quinonoid and benzenoid units, repectively. The bands at 1299 and $1245 \mathrm{~cm}^{-1}$ represented the $\mathrm{C}-\mathrm{N}$ stretching mode of benzenoid unit while the band at $1127 \mathrm{~cm}^{-1}$ reflects the plane bending vibration of $\mathrm{C}=\mathrm{N}$. The bands at $796 \mathrm{~cm}^{-1}$ represented the $\mathrm{C}-\mathrm{H}$ stretching mode of benzenoid rings [27]. Furthermore, as seen in Figure 4, the optical responses investigated by UV-vis Diffuse Reflectance Spectra (DRS) for $\mathrm{TiO}_{2}$ and $\mathrm{PANI} / \mathrm{TiO}_{2} \mathrm{NT}$ samples exhibit a notable absorption extension in the visible-light region at $420 \mathrm{~nm}$ upon the incorporation of PANI, which corresponds to a reduced bandgap absorption edge of $2.9 \mathrm{eV}$. It could be inferred from the red shift of the absorption wavelength that the $\mathrm{PANI} / \mathrm{TiO}_{2} \mathrm{NTs}$ would be an effective visible-light driven photocatalytic material.

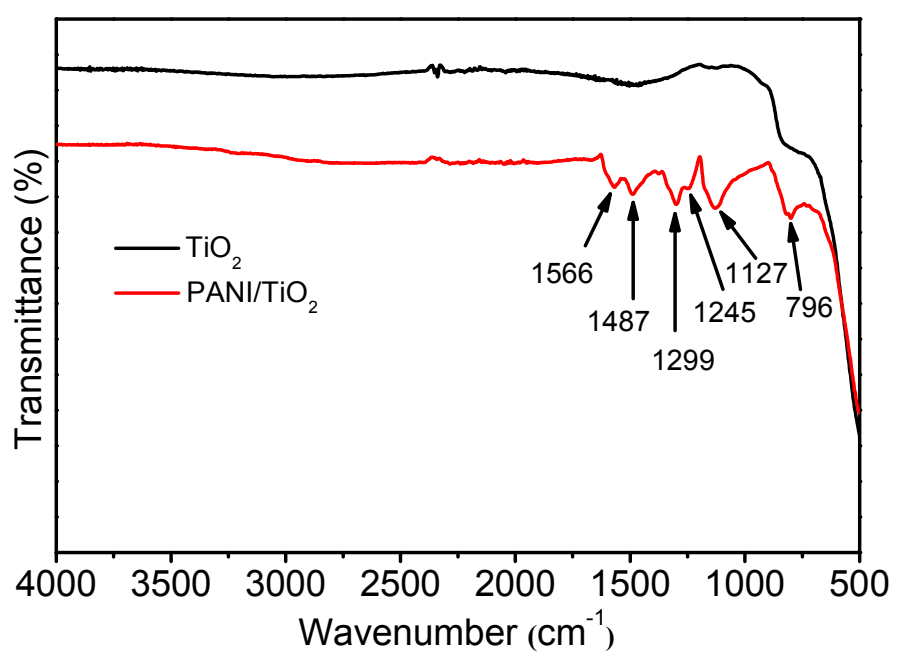

Figure 3. FTIR spectra of the $\mathrm{TiO}_{2}$ and $\mathrm{PANI} / \mathrm{TiO}_{2} \mathrm{NTs}$.

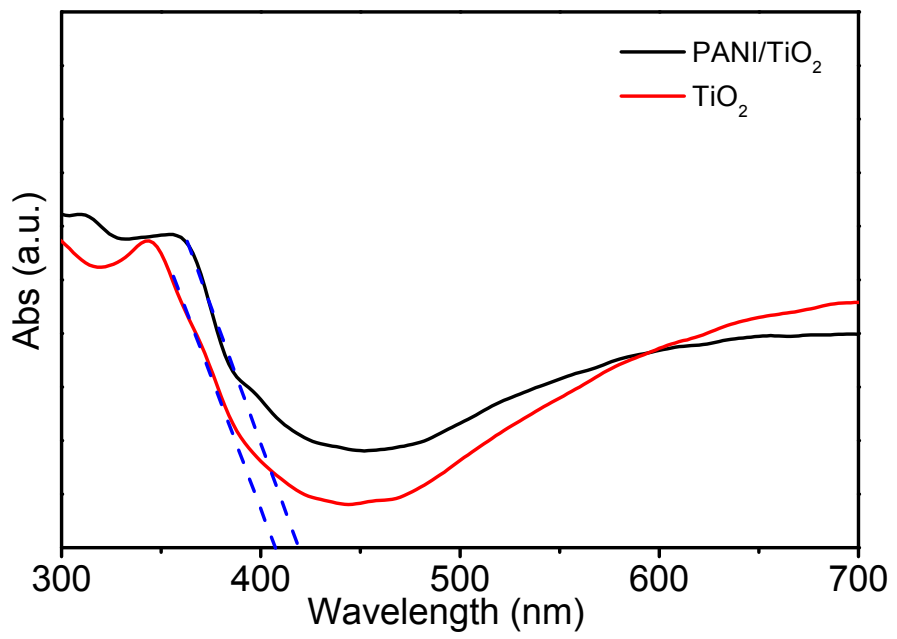

Figure 4. UV-vis diffuse reflection spectra of the $\mathrm{TiO}_{2}$ and $\mathrm{PANI} / \mathrm{TiO}_{2} \mathrm{NTs}$.

In order to understand the separation and recombination of electron-hole pairs that take place in the photocatalytic materials, the photocurrent and the electrochemical impedance spectra (EIS) measurements were carried out under visible-light irradiation. The transient photocurrent responses of $\mathrm{TiO}_{2}$ and $\mathrm{PANI} / \mathrm{TiO}_{2} \mathrm{NTs}$ electrodes were recorded via several on-off cycles of irradiation, and the 
representative traces observed are shown in Figure 5a. Obviously, the intensity of photocurrent response was found to be higher for PANI/TiO 2 NTs $\left.(50 \mu \mathrm{A} \mathrm{cm})^{-2}\right)$ than that for $\mathrm{TiO}_{2} \mathrm{NTs}$. The respective Nyquist plots of the $\mathrm{TiO}_{2}$ and $\mathrm{PANI} / \mathrm{TiO}_{2}$ NTs photoelectrodes were shown in Figure $5 \mathrm{~b}$. The semicircle at high frequencies was characteristic of the charge transfer process and its diameter was equal to the charge transfer resistance. The PANI/ $\mathrm{TiO}_{2} \mathrm{NTs}$ sample showed a smaller semicircle than that of $\mathrm{TiO}_{2}$ sample in the Nyquist plots. This clearly confirms that the rate of electron transfer between the interface of $\mathrm{PANI} / \mathrm{TiO}_{2} \mathrm{NTs}$ and the electrolyte was improved as a result of the deposition of PANI which causes the enhanced photoelectrochemical activity of the former compared with that of the latter.

The effects analysis of radicals was carried out in the present study to establish the PEC degradation mechanism as it is proved to be an effective approach in predicting the photodegradation reaction pathways of organic molecules that take place on the surface of the photocatalyst. The nature of interaction between the chosen scavenger and the photocatalyst makes a prominent impact on the efficiency of organic pollutant degradation. The scavengers used in this study were sodium oxalate $\left(\mathrm{Na}_{2} \mathrm{C}_{2} \mathrm{O}_{4}\right)$ of $0.5 \mathrm{mmol} \mathrm{L}^{-1}$ [28,29], isopropanol of $1 \mathrm{mmol} \mathrm{L}^{-1}$ [30], $\mathrm{Cr}(\mathrm{VI})$ of $0.05 \mathrm{mmol} \mathrm{L}^{-1}$ [28], and p-benzoquinone of $0.5 \mathrm{mmol} \mathrm{L}^{-1}[29,30]$ against $\mathrm{h}^{+}, \bullet \mathrm{OH}, \mathrm{e}^{-}$and $\mathrm{O}_{2}{ }^{\bullet-}$, respectively.
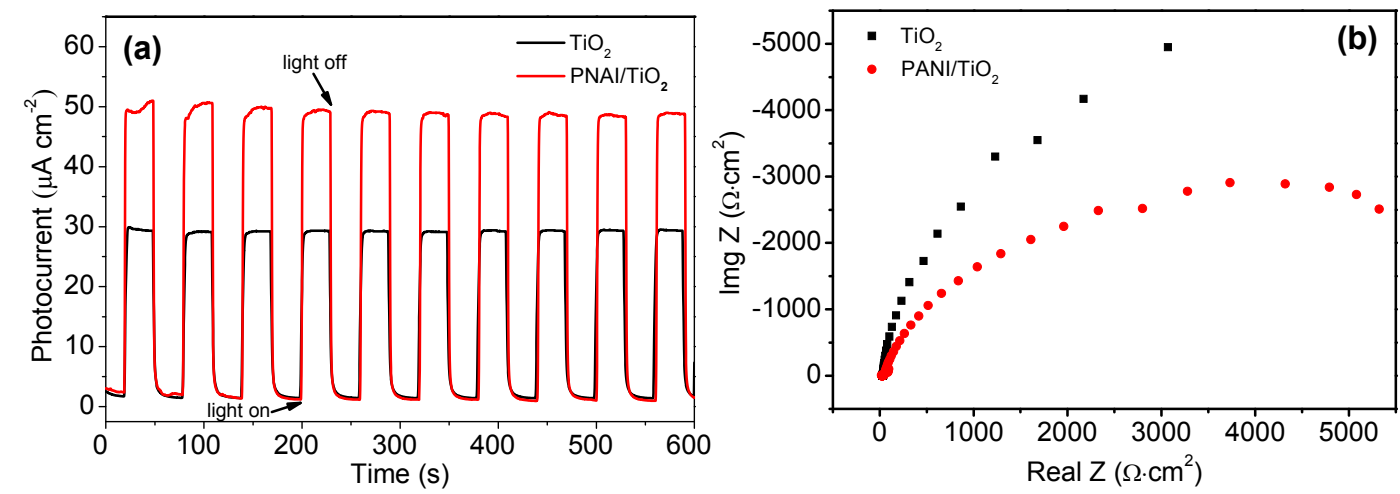

Figure 5. (a) Photocurrent responses of $\mathrm{TiO}_{2}$ and $\mathrm{PANI} / \mathrm{TiO}_{2} \mathrm{NTs}$ in $0.1 \mathrm{~mol} \mathrm{~L}-1 \mathrm{Na}_{2} \mathrm{SO}_{4}$ at a bias potential of $+0.6 \mathrm{~V}$ (vs. saturated calomel electrode (SCE)); (b) Nyquist plots of $\mathrm{TiO}_{2}$ and $\mathrm{PANI} / \mathrm{TiO}_{2}$ NTs measured at open circuit potential under irradiation.

As shown in Figure 6, in the absence of a scavenger, the PEC degradation of Rhodamine B on $\mathrm{TiO}_{2}$ sample at three hours was to an extent of $53 \%$, and it was decreased to $29.4 \%, 35.8 \%$ and $32 \%$, with the addition of scavengers $\mathrm{Na}_{2} \mathrm{C}_{2} \mathrm{O}_{4}$, isopropanol and p-benzoquinone, respectively, as a separate experiment. However, in the case of $\mathrm{Cr}(\mathrm{VI})$ addition, no prominent difference was observed in the efficiency of PEC degradation (52.6\%), which could be attributed to the following facts. The addition of $\mathrm{Cr}(\mathrm{VI})$ accepts photoelectron and suppresses the reduction of oxygen that results in a decreased production of $\mathrm{O}_{2}{ }^{\bullet-}$, which in turn restrains the degradation of Rhodamine B. On the other hand, $\mathrm{Cr}(\mathrm{VI})$ inhibits the recombination of the photoinduced electron and the hole to a certain extent, which could reversely promote the efficiency of PEC degradation. Hence, the addition of $\mathrm{Cr}(\mathrm{VI})$ has no impact on the PEC degradation of Rhodamine B. It could be inferred that the major reactive species formed on pure $\mathrm{TiO}_{2}$ were $\mathrm{h}^{+}, \mathrm{O}_{2}{ }^{\bullet-}$ and $\bullet \mathrm{OH}$.

For the PANI $/ \mathrm{TiO}_{2} \mathrm{NTs}$, under similar experimental conditions, the PEC degradation of Rhodamine $\mathrm{B}$ decreased from $77 \%$, an actual efficiency obtained without scavenger, to $27.7 \%, 45 \%$ and $28.4 \%$ with the addition of $\mathrm{Na}_{2} \mathrm{C}_{2} \mathrm{O}_{4}$, isopropanol and p-benzoquinone, respectively. Further, with the addition of $\mathrm{Cr}(\mathrm{VI})$ scavenger, the PEC degradation of Rhodamine B decreased to an extent of $60.4 \%$. The results suggest that the major reactive species formed on $\mathrm{PANI} / \mathrm{TiO}_{2} \mathrm{NTs}$ photocatalyst were $\mathrm{e}^{-}$, $\mathrm{h}^{+}, \bullet \mathrm{OH}$, and $\mathrm{O}_{2}{ }^{\bullet-}$ with an order of influence as $\mathrm{h}^{+}>\mathrm{O}_{2}{ }^{\bullet-}>\bullet \mathrm{OH}>\mathrm{e}^{-}$. 


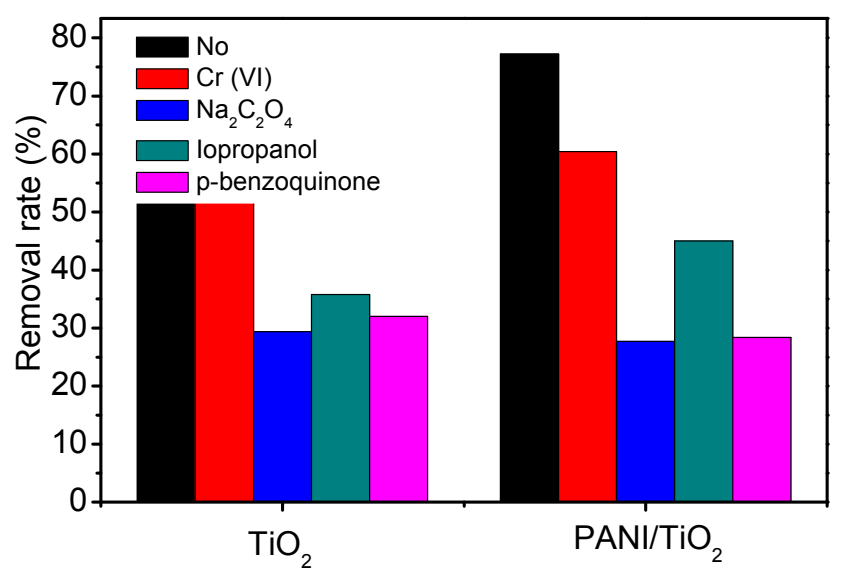

Figure 6. Effects of different scavengers on the PEC degradation of Rhodamine $\mathrm{B}\left(0.05 \mathrm{mmol} \mathrm{L}^{-1}\right.$ $\mathrm{Cr}(\mathrm{VI})$ : $\mathrm{e}^{-}$scavenger, $1 \mathrm{mmol} \mathrm{L}^{-1}$ isopropanol: $\bullet \mathrm{OH}$ scavenger, $0.5 \mathrm{mmol} \mathrm{L}^{-1}$ p-benzoquinone: $\mathrm{O}_{2}{ }^{--}$, $0.5 \mathrm{mmol} \mathrm{L}^{-1}$ sodium oxalate: $\mathrm{h}^{+}$scavenger).

\subsection{Characterization of $\mathrm{CuO} / \mathrm{Co}_{3} \mathrm{O}_{4}$ NRs Photocathode}

The SEM images recorded for as-prepared $\mathrm{Co}_{3} \mathrm{O}_{4}$ and $\mathrm{CuO}$-coated $\mathrm{Co}_{3} \mathrm{O}_{4}\left(\mathrm{CuO} / \mathrm{Co}_{3} \mathrm{O}_{4}\right)$ nanorods on the Ti substrate, are shown in Figure $7 \mathrm{a}, \mathrm{b}$ respectively. As seen, the diameter of the former was observed to be about $150 \mathrm{~nm}$. The $\mathrm{CuO} / \mathrm{Co}_{3} \mathrm{O}_{4}$ nanorods were fabricated by conducting 30 cycles of pulsed electrodeposition in the aqueous media containing both $\mathrm{CuSO}_{4}$ and lactic acid, followed by an annealing step. As the deposition cycles increase, the $\mathrm{CuO}$ NPs started covering the surface of $\mathrm{Co}_{3} \mathrm{O}_{4}$ NRs (Figure 7c) gradually and upon 40 cycles, the entire surface was completely covered by $\mathrm{CuO}$ NPs which makes it weaken in the adsorption of incident light. The XRD pattern (Figure $8 b$ ) revealed the crystal structure and phase purity of both $\mathrm{Co}_{3} \mathrm{O}_{4} \mathrm{NRs}$ and $\mathrm{CuO} / \mathrm{Co}_{3} \mathrm{O}_{4}$ NR heterostructures. For $\mathrm{CO}_{3} \mathrm{O}_{4}$ NRs, all peaks in the pattern could be indexed using the $\mathrm{Co}_{3} \mathrm{O}_{4}$ anatase phase (JPCDS No: $42-1467)$, and the intense peak of $2 \theta$ at $19.0^{\circ}, 31.2^{\circ}$ and $36.5^{\circ}$ could be correlated to (111), (200) and (311) plane diffractions, respectively. With the loading of $\mathrm{CuO} N \mathrm{NP}$, an additional peak of $2 \theta$ at $35.5^{\circ}$ was observed in the (111) orientation [31]. This indicates that the deposit made on $\mathrm{Co}_{3} \mathrm{O}_{4} \mathrm{NRs}$ was only in the form of $\mathrm{CuO}$ and not as $\mathrm{Cu}$ or $\mathrm{Cu}_{2} \mathrm{O}$. As seen in the UV-vis DRS recorded for $\mathrm{CuO} / \mathrm{Co}_{3} \mathrm{O}_{4}$ NR sample (Figure $8 b$ ), a strong absorption was observed in the visible-light region with the band gap energy of $2.33 \mathrm{eV}$ by a linear extrapolation in the absorption edge of the spectrum.
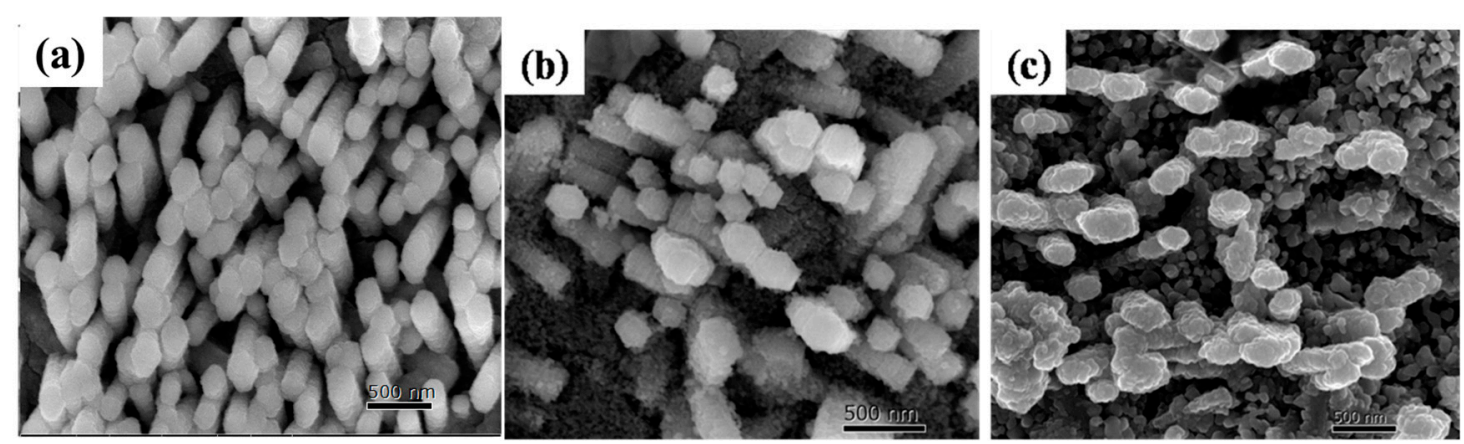

Figure 7. SEM images of the $\mathrm{Co}_{3} \mathrm{O}_{4}(\mathbf{a}), \mathrm{CuO}(30) / \mathrm{Co}_{3} \mathrm{O}_{4}(\mathbf{b})$ and $\mathrm{CuO}(40) / \mathrm{Co}_{3} \mathrm{O}_{4}$ (c). 

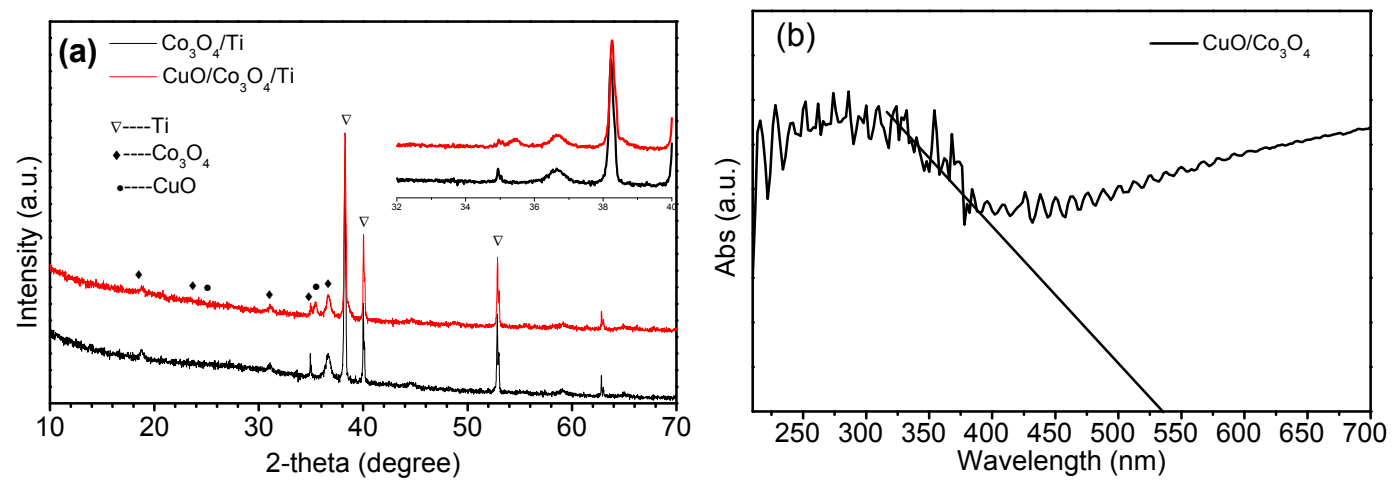

Figure 8. (a) XRD of the $\mathrm{Co}_{3} \mathrm{O}_{4}$ and $\mathrm{CuO}(30) / \mathrm{Co}_{3} \mathrm{O}_{4},(\mathbf{b}) \mathrm{UV}$-vis DRS of $\mathrm{CuO}(30) / \mathrm{Co}_{3} \mathrm{O}_{4}$.

The influence of content of $\mathrm{CuO}$ NRs on the PEC performance of $\mathrm{CuO} / \mathrm{Co}_{3} \mathrm{O}_{4}$ was studied. The NRs were fabricated by pulsed electrodeposition of different cycles, viz. 10, 20, 30 and 40 . Figure 9 a shows the comparative transient photocurrent response observed in applying the alternative on-off visible-light illumination cycles at $-0.25 \mathrm{~V}$ (vs. SCE). The $\mathrm{CuO} / \mathrm{Co}_{3} \mathrm{O}_{4} \mathrm{NRs}$ showed an instant photoresponse under irradiation, and the photocurrent densities started increasing initially as the coating cycle increases from 10 to 30, followed by a decrease with a further increase up to 40 cycles. The maximum photocurrent density of about $170 \mu \mathrm{A} \mathrm{cm}-2$ was observed for $\mathrm{CuO} / \mathrm{Co}_{3} \mathrm{O}_{4} \mathrm{NRs}$ at a coating cycle of 30 . Figure $9 \mathrm{~b}$ shows a linear sweep study for $\mathrm{CuO} / \mathrm{Co}_{3} \mathrm{O}_{4} \mathrm{NRs}$ processed in the potential range of $-0.35 \mathrm{~V}$ to $+0.01 \mathrm{~V}$ (vs. SCE) under chopped visible-light irradiation with a scan rate of $0.5 \mathrm{mV} \mathrm{s}^{-1}$. With a cathodic potential scanning, the photocurrent was observed to be increased gradually, which is in accordance with the property of a p-type semiconductor [31]. The $\mathrm{CuO} / \mathrm{Co}_{3} \mathrm{O}_{4}$ NRs, prepared by 30 cycles of pulsed electrodeposition was chosen as the photocathode for the PFC system of present study as it exhibits the best photoactivity.
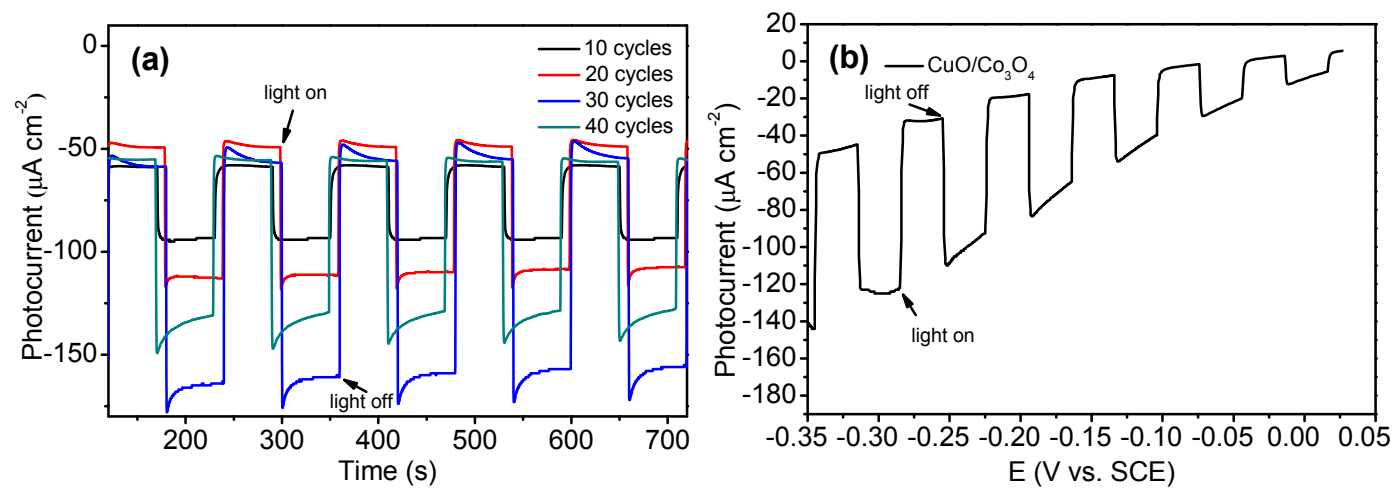

Figure 9. (a) PEC performance of the composite samples prepared at different pulse cycles at $-0.25 \mathrm{~V}$ (vs. SCE) under visible-light irradiation in $0.1 \mathrm{~mol} \mathrm{~L}^{-1} \mathrm{Na}_{2} \mathrm{SO}_{4}$ aqueous solution and (b) Linear sweep voltammetry (LSV) curves of $\mathrm{CuO}(30) / \mathrm{Co}_{3} \mathrm{O}_{4}$ in 0.1 mol L ${ }^{-1} \mathrm{Na}_{2} \mathrm{SO}_{4}$ solution in dark and under visible-light irradiation.

\subsection{Characterization of PFC System and Its Performances}

Figure 10 shows the Mott-Schottky (MS) plots depicted as $1 / \mathrm{C}^{2}$ vs. potential at $100 \mathrm{~Hz}$ for the respective PANI/ $\mathrm{TiO}_{2} \mathrm{NTs}$ and $\mathrm{CuO} / \mathrm{Co}_{3} \mathrm{O}_{4}$ NRs samples. The slopes of the linear part of the curves in the MS plot for the $\mathrm{PANI} / \mathrm{TiO}_{2}$ NTs were positive, which is a characteristic behavior of typical n-type semiconductor. The linear parts of the curves were $x$-extrapolated to zero, to obtain

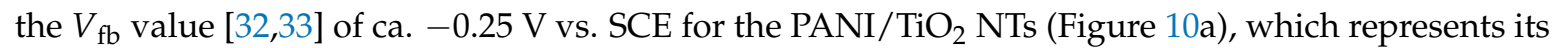
conduction band edge (CB). Conversely, the p-type characteristic behavior of $\mathrm{CuO} / \mathrm{Co}_{3} \mathrm{O}_{4} \mathrm{NRs}$ was 
verified by a negative slope in the MS plot, as seen in Figure 10b. The valence band (VB) edge $+0.58 \mathrm{~V}$ vs. SCE was approximately equal to the flatband position.
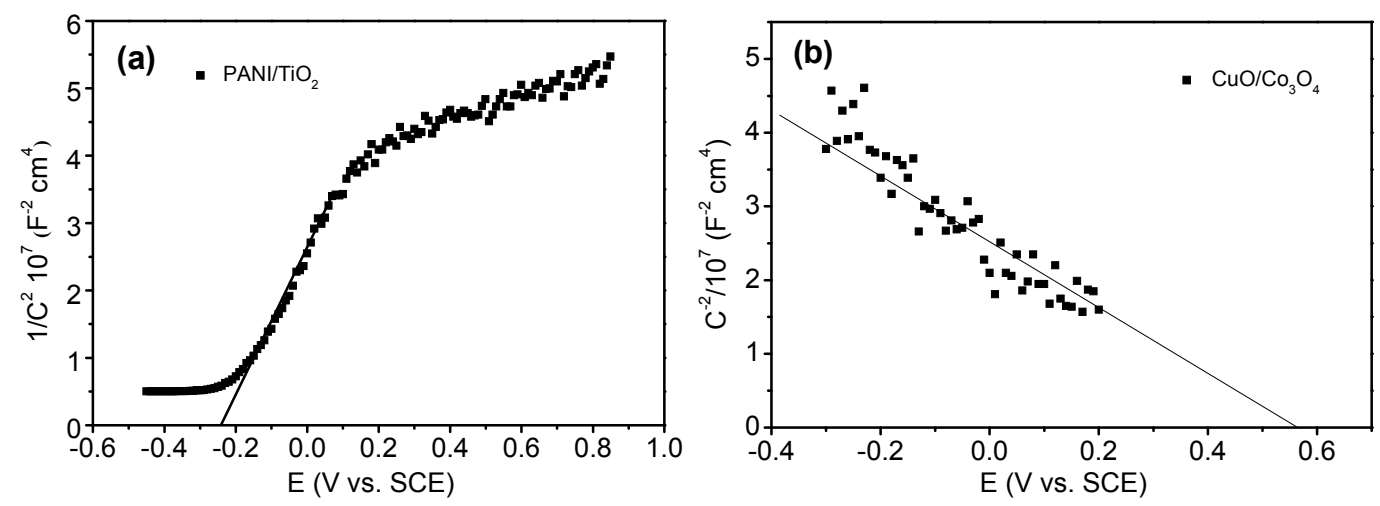

Figure 10. Mott-Schottky plots measured at a frequency of $100 \mathrm{~Hz}$ of (a) PANI/TiO 2 NTs, (b) $\mathrm{CuO} / \mathrm{Co}_{3} \mathrm{O}_{4} \mathrm{NRs}$ in the dark.

The energy band positions of the photoanode and photocahotde are illustrated in Figure 11a. As the Fermi level of $\mathrm{CuO} / \mathrm{Co}_{3} \mathrm{O}_{4} \mathrm{NRs}$ is more positive than that of $\mathrm{PANI} / \mathrm{TiO}_{2} \mathrm{NTs}$, an interior bias could be formed by connecting the two photoelectrodes directly, which would obviously drive the electrons generated from $\mathrm{PANI} / \mathrm{TiO}_{2} \mathrm{NTs}$ through the external circuit and combine with the holes generated in $\mathrm{CuO} / \mathrm{Co}_{3} \mathrm{O}_{4}$ NRs. Meanwhile, the holes and the electrons remained in the respective photoelectrode can be very well utilized for degradation of organic pollutant. It is actually the key factor that makes the PEC technique successful by combining n-type photoanode and p-type photocathode.

The open circuit potential $\left(E_{\text {ocp }}\right)$ was established from the difference in the Fermi level of the two photoelectrodes [32,33]. To examine the photoelectric properties of the PFC, the photovoltage curves of the PFC system of $\mathrm{PANI} / \mathrm{TiO}_{2}-\mathrm{CuO} / \mathrm{Co}_{3} \mathrm{O}_{4}$ was measured in the dark and under irradiation. $E_{\text {ocp }}$ of the PANI/ $\mathrm{TiO}_{2}$ NTs photoanode and the $\mathrm{CuO} / \mathrm{Co}_{3} \mathrm{O}_{4}$ NRs photocathode were measured to be $-0.13 \mathrm{~V}$ and $0.12 \mathrm{~V}$, respectively, under visible-light irradiation $\left(3 \mathrm{~mW} \mathrm{~cm}^{-2}\right)$. It implies that the photovoltage between the photocathode and the photoanode would be $+0.25 \mathrm{~V}$ which is consistent with the measured value $(+0.24 \mathrm{~V})$ of the PFC system, as shown in Figure $11 \mathrm{~b}$. As a result, the separation of the electron/hole pair in the photoelectrodes could be facilitated in parallel under visible-light irradiation.
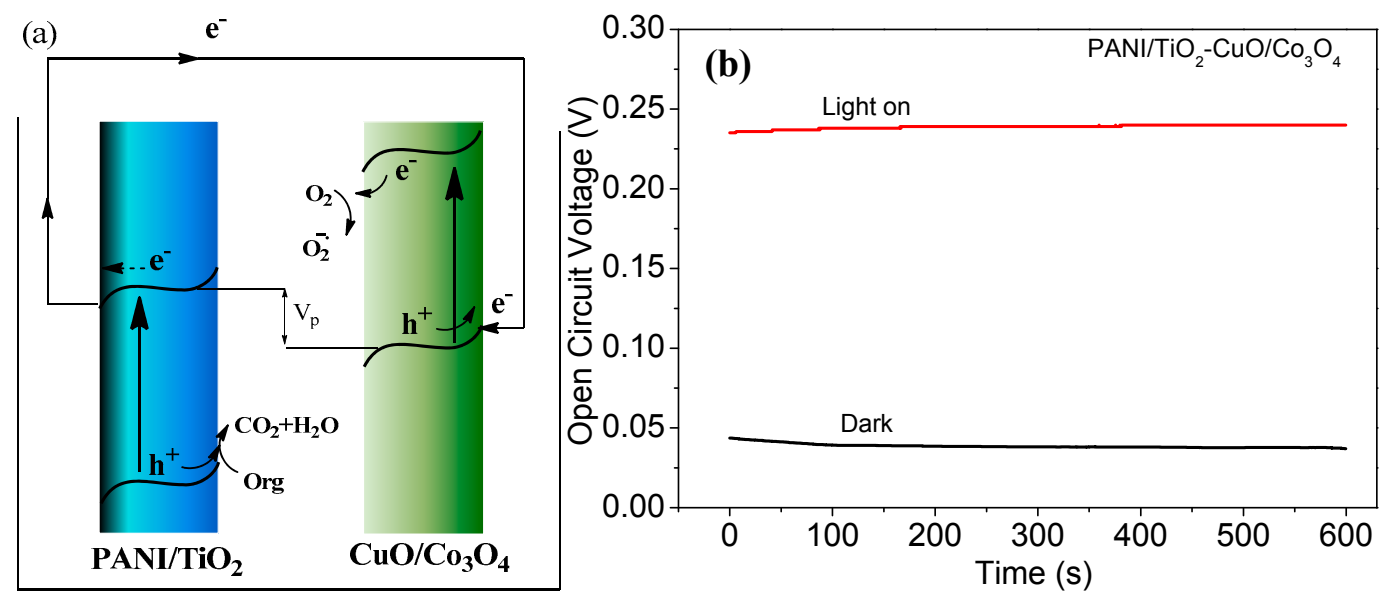

Figure 11. (a) Energy level diagram of the PFC cell for organic compounds degradation and electricity generation, (b) The open-circuit voltage of $\mathrm{PFC}$ cell of $\mathrm{PANI} / \mathrm{TiO}_{2}-\mathrm{CuO} / \mathrm{Co}_{3} \mathrm{O}_{4}$ in dark and under visible-light irradiation. 


\subsection{Degradation of Rhodamine $B$}

The performance of the PFC system was evaluated by a degradation study on Rhodamine $B$ contaminated aqueous solution under visible-light irradiation. The degradation efficiency was monitored in terms of decolorization of Rhodamine B. The photocatalytic activity of various systems using different types of photocatalysts was compared under incandescent light irradiation as shown in Figure 12a. As seen, the photocatalytic activity of the system in which the photoelectrodes are not externally interconnected, was found to be inferior to the others and showing a decolorization of Rhodamine B of only $25.4 \%$. For the PFC system of different photoelectrode couples $\mathrm{TiO}_{2}-\mathrm{CuO} / \mathrm{Co}_{3} \mathrm{O}_{4}$, and $\mathrm{PANI} / \mathrm{TiO}_{2}-\mathrm{CuO} / \mathrm{Co}_{3} \mathrm{O}_{4}$ the decolorization was $51 \%$ and $68 \%$, respectively at same reaction period. Figure $12 \mathrm{~b}$ demonstrates that the short-circuit current density curve obtained for the present PFC system $\left(\mathrm{PANI} / \mathrm{TiO}_{2}-\mathrm{CuO} / \mathrm{Co}_{3} \mathrm{O}_{4}\right)$ during the process of Rhodamine $\mathrm{B}$ decolorization, was relatively steady with a current density of $85 \mu \mathrm{A} \mathrm{cm} \mathrm{cm}^{-2}$ throughout the process. The consistent photocurrent density observed for the PFC confirmed its photostability and durability for long-time application.
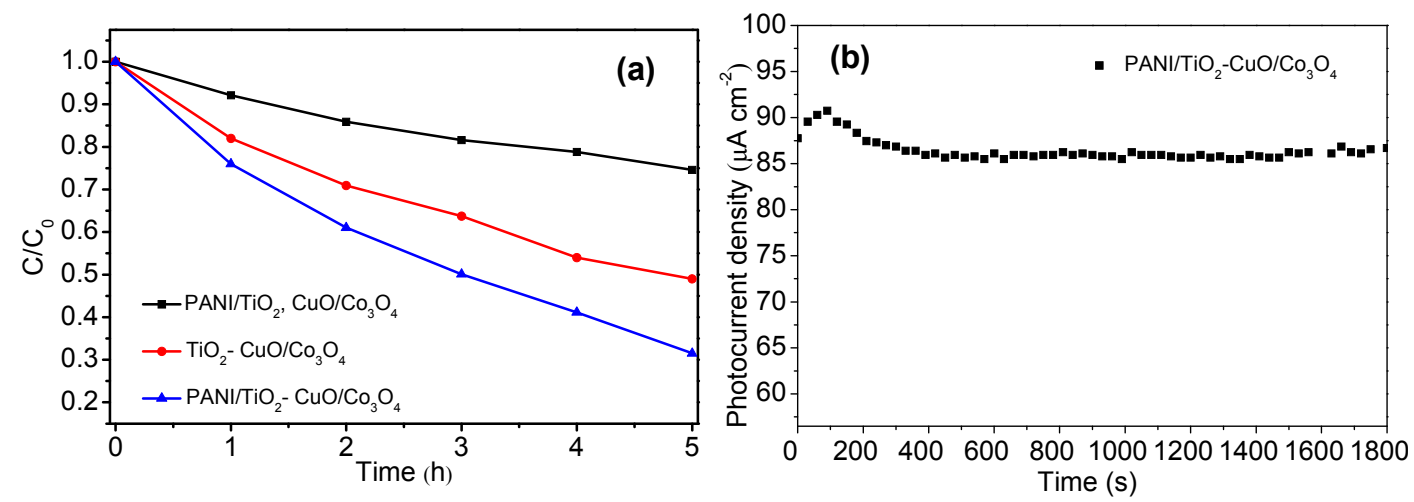

Figure 12. (a) Comparison of the degradation rates of Rhodamine $\mathrm{B}$ in the photocatalytic decomposition processes using unconnected $\mathrm{PANI} / \mathrm{TiO}_{2}$ and $\mathrm{CuO} / \mathrm{Co}_{3} \mathrm{O}_{4}$ photoelectrodes, the PFC systems of $\mathrm{TiO}_{2} \mathrm{CuO} / \mathrm{Co}_{3} \mathrm{O}_{4}$ and $\mathrm{PANI} / \mathrm{TiO}_{2}-\mathrm{CuO} / \mathrm{Co}_{3} \mathrm{O}_{4},(\mathbf{b})$ the generated electricity of the PFC.

\section{Materials and Methods}

\subsection{Chemical and Material}

Titanium foil with a thickness of $1 \mathrm{~mm}$ and a purity of $99.9 \%$ was purchased from Strem Chemicals (Newburyport, MA, USA). The chemicals such as ethylene glycol (EG), ammonia fluoride $\left(\mathrm{NH}_{4} \mathrm{~F}\right)$, sodium sulfate $\left(\mathrm{Na}_{2} \mathrm{SO}_{4}\right)$, phenylamine $\left(\mathrm{C}_{6} \mathrm{H}_{5} \mathrm{NH}_{2}\right)$, cobalt nitrate hexahydrate $\left(\mathrm{Co}\left(\mathrm{NO}_{3}\right)_{2} \cdot 6 \mathrm{H}_{2} \mathrm{O}\right)$, hexamethylenetetramine $\left(\mathrm{C}_{6} \mathrm{H}_{12} \mathrm{~N}_{4}, \mathrm{HMT}\right)$, sodium persulfate $\left(\mathrm{Na}_{2} \mathrm{~S}_{2} \mathrm{O}_{3}\right)$ and $\mathrm{HCl}$ were purchased from Acros Organics (Pittsburgh, PA, USA) and used as received. The aqueous solution used was prepared by using a millipore deionized (DI) water with a resistivity of $18.2 \mathrm{M} \Omega \mathrm{cm}$.

\subsection{Preparation of $\mathrm{PANI} / \mathrm{Ti} \mathrm{O}_{2}-\mathrm{NTS}$}

The self-organized $\mathrm{TiO}_{2}$ nanotube arrays $\left(\mathrm{TiO}_{2}-\mathrm{NTs}\right)$ were fabricated on $\mathrm{Ti}$ foil substrate by anodization method using ethylene glycol (EG) as electrolyte media which contains $0.5 \mathrm{wt} \% \mathrm{NH}_{4} \mathrm{~F}$ and $10 \mathrm{vol} \%$ water. The fabrication process was described in detail in our previous studies [34]. The anodization of Ti foil was performed with a two-electrode electrochemical system employing $\mathrm{Pt}$ mesh as cathode at a constant operating potential of $20 \mathrm{~V}$ for a period of $2 \mathrm{~h}$. The inter electrode gap was fixed as $3 \mathrm{~cm}$ for every electrolysis run. In the post treatment, the anodized sample was washed with millipore deionized water, dried at $70{ }^{\circ} \mathrm{C}$ and calcined at $450{ }^{\circ} \mathrm{C}$ for $2 \mathrm{~h}$.

The PANI/ $\mathrm{TiO}_{2}$ NTs composite was synthesized by a sequential chemical bath deposition (SCBD) method. Typically, the $\mathrm{TiO}_{2}$ NTs was successively immersed into four different glass beakers for about 
$30 \mathrm{~min}$ in each beaker. The first beaker contained aqueous solution of $0.27 \mathrm{~mol} \mathrm{~L}^{-1}$ of phenylamine, and the third one contained an aqueous mixture of $0.23 \mathrm{~mol} \mathrm{~L}^{-1}$ of sodium persulfate and $0.15 \mathrm{~mol} \mathrm{~L}^{-1}$ of $\mathrm{HCl}$, and the other two contained distilled water to rinse the samples to scavenge the excess of each precursor solution. Such an immersion treatment cycle was repeated thrice.

\subsection{Preparation of $\mathrm{CuO} / \mathrm{Co}_{3} \mathrm{O}_{4}$}

The synthesis of $\mathrm{Co}_{3} \mathrm{O}_{4}$ electrode was accomplished by a simple hydrothermal process [35]. $7.2 \mathrm{~g}$ of $\mathrm{Co}\left(\mathrm{NO}_{3}\right)_{2} \cdot 6 \mathrm{H}_{2} \mathrm{O}, 0.13 \mathrm{~g}$ of $\mathrm{NH}_{4} \mathrm{~F}$, and $0.3 \mathrm{~g}$ of HMT were dissolved in the order in a $50-\mathrm{mL}$ acetone-deionized water $(v / v=50: 50)$ mixture solution under continuous stirring using magnetic stirrer. Upon a formation of pink suspension, the stirring was continued for another $10 \mathrm{~min}$. Then the suspension, together with a Ti film, was transformed to a teflon-lined stainless-steel autoclave vessel and kept for $24 \mathrm{~h}$ at $95{ }^{\circ} \mathrm{C}$. The pink-depositions-covered-Ti film was obtained by these steps, and carefully rinsed with deionized water and dried at $70{ }^{\circ} \mathrm{C}$, followed by a calcination process at $350{ }^{\circ} \mathrm{C}$ for $1 \mathrm{~h}$ in air environment. The transformation of pink depositions into black one upon calcinations confirmed the formation of $\mathrm{Co}_{3} \mathrm{O}_{4}$.

$\mathrm{CuO}$ was prepared by a pulsed galvanostat method under high current conditions [36]. The electrodeposition was carried out in a conventional three-electrode electrochemical workstation (CS310, CorrTest, Wuhan, China) with a conditioned electrolyte solution of $0.4 \mathrm{~mol} \mathrm{~L}^{-1} \mathrm{CuSO}_{4}$ and $3 \mathrm{~mol} \mathrm{~L}-1$ lactic acid fixing the $\mathrm{pH}$ at 7 by $\mathrm{NaOH}$ and the temperature at $25^{\circ} \mathrm{C}$. The concentrated lactic acid acts as a complex agent for the stabilization of copper ions [37]. Upon subjecting to a negative current pulse for $0.5 \mathrm{~s}$ followed by a constant current density of $50 \mathrm{~mA}$ for $7 \mathrm{~s}$, the surface of the $\mathrm{Co}_{3} \mathrm{O}_{4}$ was covered with $\mathrm{Cu}$ nanoparticles (NPs). The as-prepared electrode was carefully rinsed with millipore deionized water and dried at $70{ }^{\circ} \mathrm{C}$, followed by a calcination process at $350{ }^{\circ} \mathrm{C}$ for $1 \mathrm{~h}$. Then the samples were rinsed with ethanol, followed by a heat treatment at $450^{\circ} \mathrm{C}$ for $1 \mathrm{~h}$ in air environment. In order to optimize the deposition of $\mathrm{CuONPs}$ on the $\mathrm{Co}_{3} \mathrm{O}_{4}$, the samples were fabricated at different pulse cycles, viz. 10, 20, 30 and 40 .

\subsection{Characterization}

The morphology and microstructure of the synthesized samples were characterized by field emission scanning electron microscopy (FE-SEM; NANOSEM 450, FEI, Eindhoven, The Netherlands). The phase and elemental composition of the samples were investigated using X-ray Diffraction Technique (XRD; PW3040/60 PANalytical, Almelo, The Netherlands) with $\mathrm{Cu} \mathrm{K} \alpha$ radiation $(\lambda=1.54056 \AA)$. UV-visible spectrum scanning was carried out in the range of $200-800 \mathrm{~nm}$ using a UV-2550 model UV-visible spectrophotometer (Shimadzu Corporation, Kanagawa, Japan) at room temperature. The infrared absorption spectra were measured on a Bruker V-70 Fourier transform infrared (FTIR, Bruker, Karlsruhe, Germany) spectrophotometer in the frequency range of 400 to $4000 \mathrm{~cm}^{-1}$.

The photoresponsive test was carried out for the sample (either PANI/ TiO 2 NTs or $\mathrm{CuO} / \mathrm{Co}_{3} \mathrm{O}_{4}$ NRs) used as working electrode in a three-electrode electrochemical work station (CS310, CorrTest, Wuhan, China), wherein saturated calomel electrode (SCE) and Pt foil was used as reference and auxiliary electrodes, respectively. The electrochemical impedance spectroscopic (EIS) studies were performed between $100 \mathrm{kHz}$ and $0.01 \mathrm{~Hz}$ with a $5 \mathrm{mV}$ rms sinusoidal modulation at the open circuit potential of the system under illumination. The linear sweep was evaluated under chopped light irradiation with a scan rate of $0.5 \mathrm{mV} \mathrm{s}^{-1}$. Mott-Schottky plots were measured at a frequency of $100 \mathrm{~Hz}$. The electrochemical studies described above were carried out in a $0.1 \mathrm{~mol} \mathrm{~L}^{-1} \mathrm{Na}_{2} \mathrm{SO}_{4}$ aqueous solution at room temperature. The light source used was a $11 \mathrm{~W}$ incandescent lamp (PHILPS, Amsterdam, The Netherlands) that produced irradiation with an intensity of $3 \mathrm{~mW} \mathrm{~cm}^{-2}$ to the test sample which was measured by a visible-light radiometer (FZ-A, Wuhan, China).

The photoelectrochemical characteristics of the PFC were examined by connecting PANI/ $\mathrm{TiO}_{2}$ NTs electrode and $\mathrm{CuO} / \mathrm{Co}_{3} \mathrm{O}_{4}$ NRs electrode directly. The short circuit current plot, and the open 
circuit potentials plot as well as the characteristic nature of photocurrent potentials were tested by digit precision multimeter (Tektronix DMM4050, Johnston, OH, USA) and the electrochemical workstation, respectively.

\subsection{Photoelectrocatalytic Degradation of Phenol under Visible-Light Irradiation}

Photoelectrocatalytic oxidation experiments were carried out in a glass container having volume capacity of $150 \mathrm{~mL}$ with a standard three-electrode configuration using synthesized $\mathrm{PANI} / \mathrm{TiO}_{2}$-NTs as photoanode, a Pt foil and a SCE as counter and reference electrodes, respectively. The photoelectrochemical degradation experiments were performed with a working volume of $45 \mathrm{~mL}$ aqueous solution containing a model contaminant Rhodamine $\mathrm{B}\left(1 \times 10^{-5} \mathrm{~mol} \mathrm{~L}^{-1}\right)$ along with $0.1 \mathrm{~mol} \mathrm{~L}^{-1} \mathrm{Na}_{2} \mathrm{SO}_{4}$ as supporting electrolyte. The glass container was placed in a water bath wherein the temperature was constantly maintained as $298 \mathrm{~K}$, and the entire set-up was placed on a magnetic stirrer operated at a constant stirring rate of $650 \mathrm{rpm}$ during the process. Prior to the light irradiation, the experimental solution was stirred in the dark for ca. $30 \mathrm{~min}$ to establish the adsorption/desorption equilibrium between the organic contaminant and the surface of the $\mathrm{PANI} / \mathrm{TiO}_{2}-\mathrm{NTs}$ under ambient air equilibrium. The degradation rate of Rhodamine B was followed by using a UV-vis spectrophotometer (UV2102 PCS, UNICO, Shanghai, China) in which the wavelength was fixed at $554 \mathrm{~nm}$.

The PFC degradation of Rhodamine $\mathrm{B}\left(1 \times 10^{-5} \mathrm{~mol} \mathrm{~L}^{-1}\right)$ was performed by exposing the light on both the $\mathrm{PANI} / \mathrm{TiO}_{2}-\mathrm{NTs}$ photoanode and $\mathrm{CuO} / \mathrm{Co}_{3} \mathrm{O}_{4}$ photocathode with the illumination area of $2 \times 2 \mathrm{~cm}^{2}$ under similar conditions to those followed in the photoelectrocatalytic experiment. The PFC current was measured by using a digit precision multimeter.

\section{Conclusions}

A highly efficient and visible-light responsive photocatalytic fuel cell (PFC) system involving a dual heterojuntion $\mathrm{PANI} / \mathrm{TiO}_{2}$ photoanode and $\mathrm{CuO} / \mathrm{Co}_{3} \mathrm{O}_{4}$ photocathode was constructed. The results obtained showed that a photocurrent of $50 \mu \mathrm{A} \mathrm{cm}{ }^{-2}$ was achieved using the $\mathrm{PANI} / \mathrm{TiO}_{2}$ photoanode at a bias potential of $+0.6 \mathrm{~V}$ (vs. SCE) in $0.1 \mathrm{~mol} \mathrm{~L}^{-1} \mathrm{Na}_{2} \mathrm{SO}_{4}$ electrolyte under visible-light irradiation of $3 \mathrm{~mW} \mathrm{~cm}^{-2}$, which was $150 \%$ higher than that of $\mathrm{TiO}_{2}$. Additionally, the optimized $\mathrm{CuO} / \mathrm{Co}_{3} \mathrm{O}_{4}$ photocathode exhibited a photocurrent of $170 \mu \mathrm{A} \mathrm{cm} \mathrm{cm}^{-2}$ at $-0.25 \mathrm{~V}$ (vs. SCE). The PFC was constructed with the aim of providing an internal bias potential to the photoelectrocatalytic system and the performance and working mechanism of the same were systematically investigated. Under visible-light irradiation, the interior bias $(+0.24 \mathrm{~V})$ developed, drives the electrons of the $\mathrm{PANI} / \mathrm{TiO}_{2}-\mathrm{NT}^{\prime} \mathrm{s}$ photoanode across the external circuit to combine with the holes of the $\mathrm{CuO} / \mathrm{Co}_{3} \mathrm{O}_{4}$ photocathode, which actually leads to electron/hole pair separation at respective photoelectrodes. The results obtained in the study suggest that the PFC system involving dual heterojuntion $\mathrm{PANI} / \mathrm{TiO}_{2}$ photoanode and $\mathrm{CuO} / \mathrm{Co}_{3} \mathrm{O}_{4}$ photocathode is very effective for wastewater treatment along with simultaneous electricity generation.

Acknowledgments: This work was supported by the International Science \& Technology Cooperation Program of China (Nos. 2013DFG50150 and 2016YFE0126300) and the Innovative and Interdisciplinary Team at HUST (2015ZDTD027). The authors thank the Analytical and Testing Center of HUST for the use of SEM, XRD, TEM, FTIR and DRS equipments.

Author Contributions: Yanrong Zhang and Muthu Murugananthan conceived and designed the experiments; Wenjuan Liao and Na Sun performed the experiments; Honghui Pan contributed analysis tools; Wenjuan Liao wrote the paper.

Conflicts of Interest: The authors declare no conflict of interest.

\section{References}

1. Feng, Y.; Lee, H.; Wang, X.; Liu, Y.; He, W. Continuous electricity generation by a graphite granule baffled air-cathode microbial fuel cell. Bioresour. Technol. 2010, 101, 632-638. [CrossRef] [PubMed] 
2. Strataki, N.; Antoniadou, M.; Dracopoulos, V.; Lianos, P. Visible-light photocatalytic hydrogen production from ethanol-water mixtures using a Pt-CdS- $\mathrm{TiO}_{2}$ photocatalyst. Catal. Today 2010, 151, 53-57. [CrossRef]

3. Liu, Y.; Li, J.; Zhou, B.; Li, X.; Chen, H.; Chen, Q.; Wang, Z.; Li, L.; Wang, J.; Cai, W. Efficient electricity production and simultaneously wastewater treatment via a high-performance photocatalytic fuel cell. Water Res. 2011, 45, 3991-3998. [CrossRef] [PubMed]

4. Bayati, M.R.; Golestani-Fard, F.; Moshfegh, A.Z. Visible photodecomposition of methylene blue over micro arc oxidized $\mathrm{WO}_{3}$-loaded $\mathrm{TiO}_{2}$ nano-porous layers. Appl. Catal. A 2010, 382, 322-331. [CrossRef]

5. Lu, B.; Ma, X.; Pan, C.; Zhu, Y. Photocatalytic and photoelectrochemical properties of in situ carbon hybridized $\mathrm{BiPO}_{4}$ films. Appl. Catal. A 2012, 435-436, 93-98. [CrossRef]

6. Chen, D.; Ye, J. Hierarchical $\mathrm{WO}_{3}$ Hollow Shells: Dendrite, Sphere, Dumbbell, and Their Photocatalytic Properties. Adv. Funct. Mater. 2008, 18, 1922-1928. [CrossRef]

7. Antoniadou, M.; Kondarides, D.; Labou, D.; Neophytides, S.; Lianos, P. An efficient photoelectrochemical cell functioning in the presence of organic wastes. Sol. Energy Mater. Sol. Cells 2010, 94, 592-597. [CrossRef]

8. Lianos, P. Production of electricity and hydrogen by photocatalytic degradation of organic wastes in a photoelectrochemical cell: The concept of the Photofuelcell: A review of a re-emerging research field. J. Hazard. Mater. 2011, 185, 575-590. [CrossRef] [PubMed]

9. Liu, Y.; Li, J.; Zhou, B.; Lv, S.; Li, X.; Chen, H.; Chen, Q.; Cai, W. Photoelectrocatalytic degradation of refractory organic compounds enhanced by a photocatalytic fuel cell. Appl. Catal. B 2012, 111-112, 485-491. [CrossRef]

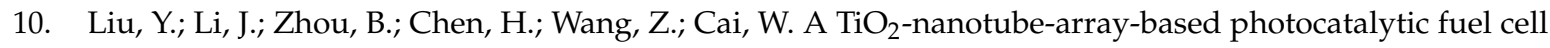
using refractory organic compounds as substrates for electricity generation. Chem. Commun. 2011, 47, 10314-10316. [CrossRef] [PubMed]

11. Georgieva, J.; Valova, E.; Armyanov, S.; Philippidis, N.; Poulios, I.; Sotiropoulos, S. Bi-component semiconductor oxide photoanodes for the photoelectrocatalytic oxidation of organic solutes and vapours: A short review with emphasis to $\mathrm{TiO}_{2}-\mathrm{WO}_{3}$ photoanodes. J. Hazard. Mater. 2012, 211-212, 30-46. [CrossRef] [PubMed]

12. Li, K.; Zhang, H.; Tang, Y.; Ying, D.; Xu, Y.; Wang, Y.; Jia, J. Photocatalytic degradation and electricity generation in a rotating disk photoelectrochemical cell over hierarchical structured BiOBr film. Appl. Catal. B 2015, 164, 82-91. [CrossRef]

13. Wang, D.; Li, Y.; Li Puma, G.; Wang, C.; Wang, P.; Zhang, W.; Wang, Q. Dye-sensitized photoelectrochemical cell on plasmonic $\mathrm{Ag} / \mathrm{AgCl} @$ chiral $\mathrm{TiO}_{2}$ nanofibers for treatment of urban wastewater effluents, with simultaneous production of hydrogen and electricity. Appl. Catal. B 2015, 168-169, 25-32. [CrossRef]

14. Du, Y.; Feng, Y.; Qu, Y.; Liu, J.; Ren, N.; Liu, H. Electricity Generation and Pollutant Degradation Using a Novel Biocathode Coupled Photoelectrochemical Cell. Environ. Sci. Technol. 2014, 48, 7634-7641. [CrossRef] [PubMed]

15. Li, J.; Li, J.; Chen, Q.; Bai, J.; Zhou, B. Converting hazardous organics into clean energy using a solar responsive dual photoelectrode photocatalytic fuel cell. J. Hazard. Mater. 2013, 262, 304-310. [CrossRef] [PubMed]

16. Chen, Q.; Li, J.; Li, X.; Huang, K.; Zhou, B.; Shangguan, W. Self-Biasing Photoelectrochemical Cell for Spontaneous Overall Water Splitting under Visible-Light Illumination. ChemSusChem 2013, 6, 1276-1281. [CrossRef] [PubMed]

17. Paracchino, A.; Laporte, V.; Sivula, K.; Grätzel, M.; Thimsen, E. Highly active oxide photocathode for photoelectrochemical water reduction. Nat. Mater. 2011, 10, 456-461. [CrossRef] [PubMed]

18. Bai, J.; Wang, R.; Li, Y.; Tang, Y.; Zeng, Q.; Xia, L.; Li, X.; Li, J.; Li, C.; Zhou, B. A solar light driven dual photoelectrode photocatalytic fuel cell (PFC) for simultaneous wastewater treatment and electricity generation. J. Hazard. Mater. 2016, 311, 51-62. [CrossRef] [PubMed]

19. Wang, H.; Zhang, L.; Chen, Z.; Hu, J.; Li, S.; Wang, Z.; Liu, J.; Wang, X. Semiconductor heterojunction photocatalysts: Design, construction, and photocatalytic performances. Chem. Soc. Rev. 2014, 43, 5234-5244. [CrossRef] [PubMed]

20. Liao, G.; Chen, S.; Quan, X.; Zhang, Y.; Zhao, H. Remarkable improvement of visible light photocatalysis with PANI modified core-shell mesoporous $\mathrm{TiO}_{2}$ microspheres. Appl. Catal. B 2011, 102, 126-131. [CrossRef]

21. Li, X.; Wang, D.; Cheng, G.; Luo, Q.; An, J.; Wang, Y. Preparation of polyaniline-modified $\mathrm{TiO}_{2}$ nanoparticles and their photocatalytic activity under visible light illumination. Appl. Catal. B 2008, 81, 267-273. [CrossRef] 
22. Liu, J.; Wang, D.; Wang, M.; Kong, D.; Zhang, Y.; Chen, J.F.; Dai, L. Uniform Two-dimensional $\mathrm{Co}_{3} \mathrm{O}_{4} \mathrm{Porous}$ Sheets: Facile Synthesis and Enhanced Photocatalytic Performance. Chem. Eng. Technol. 2016, 39, 891-898. [CrossRef]

23. Yehezkeli, O.; de Oliveira, D.R.; Cha, J.N. Electrostatically Assembled CdS- $\mathrm{Co}_{3} \mathrm{O}_{4}$ Nanostructures for Photo-assisted Water Oxidation and Photocatalytic Reduction of Dye Molecules. Small 2015, 11, 668-674. [CrossRef] [PubMed]

24. Shaabani, B.; Alizadeh-Gheshlaghi, E.; Azizian-Kalandaragh, Y.; Khodayari, A. Preparation of CuO nanopowders and their catalytic activity in photodegradation of Rhodamine-B. Adv. Powder Technol. 2014, 25, 1043-1052. [CrossRef]

25. Shi, W.; Chopra, N. Surfactant-free synthesis of novel copper oxide $(\mathrm{CuO})$ nanowire-cobalt oxide $\left(\mathrm{Co}_{3} \mathrm{O}_{4}\right)$ nanoparticle heterostructures and their morphological control. J. Nanopart. Res. 2011, 13, 851-868. [CrossRef]

26. Shi, W.; Chopra, N. Controlled fabrication of photoactive copper oxide-cobalt oxide nanowire heterostructures for efficient phenol photodegradation. ACS Appl. Mater. Interfaces 2012, 4, 5590-5607. [CrossRef] [PubMed]

27. Yavuz, A.G.; Gök, A. Preparation of $\mathrm{TiO}_{2} / \mathrm{PANI}$ composites in the presence of surfactants and investigation of electrical properties. Synth. Met. 2007, 157, 235-242. [CrossRef]

28. Liao, W.; Zhang, Y.; Zhang, M.; Murugananthan, M.; Yoshihara, S. Photoelectrocatalytic degradation of microcystin- $\mathrm{LR}$ using $\mathrm{Ag} / \mathrm{AgCl} / \mathrm{TiO}_{2}$ nanotube arrays electrode under visible light irradiation. Chem. Eng. J. 2013, 231, 455-463. [CrossRef]

29. Chen, S.; Hu, Y.; Meng, S.; Fu, X. Study on the separation mechanisms of photogenerated electrons and holes for composite photocatalysts $\mathrm{g}_{-} \mathrm{C}_{3} \mathrm{~N}_{4}-\mathrm{WO}_{3}$. Appl. Catal. B 2014, 150-151, 564-573. [CrossRef]

30. Yang, Y.; Guo, W.; Guo, Y.; Zhao, Y.; Yuan, X.; Guo, Y. Fabrication of Z-scheme plasmonic photocatalyst $\mathrm{Ag} @ \mathrm{AgBr} / \mathrm{g}-\mathrm{C}_{3} \mathrm{~N}_{4}$ with enhanced visible-light photocatalytic activity. J. Hazard. Mater. 2014, 271, 150-159. [CrossRef] [PubMed]

31. Yang, J.; Liao, W.; Liu, Y.; Murugananthan, M.; Zhang, Y. Degradation of Rhodamine B using a Visible-light driven Photocatalytic Fuel Cell. Electrochim. Acta 2014, 144, 7-15. [CrossRef]

32. Spadavecchia, F.; Cappelletti, G.; Ardizzone, S.; Ceotto, M.; Falciola, L. Electronic structure of pure and $\mathrm{N}$-doped $\mathrm{TiO}_{2}$ nanocrystals by electrochemical experiments and first principles calculations. J. Phys. Chem. C 2011, 115, 6381-6391. [CrossRef]

33. Gu, J.; Yan, Y.; Krizan, J.W.; Gibson, Q.D.; Detweiler, Z.M.; Cava, R.J.; Bocarsly, A.B. p-Type CuRhO 2 as a self-healing photoelectrode for water reduction under visible light. J. Am. Chem. Soc. 2014, 136, 830-833. [CrossRef] [PubMed]

34. Zhou, H.; Zhang, Y. Enhanced electrochemical performance of manganese dioxide spheres deposited on a titanium dioxide nanotube arrays substrate. J. Power Sources 2014, 272, 866-879. [CrossRef]

35. Huang, X.; Cao, T.; Liu, M.; Zhao, G. Synergistic Photoelectrochemical Synthesis of Formate from $\mathrm{CO}_{2}$ on $\{121\}$ Hierarchical $\mathrm{Co}_{3} \mathrm{O}_{4}$. J. Phys. Chem. C 2013, 117, 26432-26440. [CrossRef]

36. Shen, Q.; Chen, Z.; Huang, X.; Liu, M.; Zhao, G. High-yield and selective photoelectrocatalytic reduction of $\mathrm{CO}_{2}$ to formate by metallic copper decorated $\mathrm{Co}_{3} \mathrm{O}_{4}$ nanotube arrays. Environ. Sci. Technol. 2015, 49, 5828-5835. [CrossRef] [PubMed]

37. Lee, C.Y.; Lee, K.; Schmuki, P. Anodic Formation of Self-Organized Cobalt Oxide Nanoporous Layers. Angew. Chem. Int. Ed. 2013, 52, 2077-2081. [CrossRef] [PubMed]

(C) 2018 by the authors. Licensee MDPI, Basel, Switzerland. This article is an open access article distributed under the terms and conditions of the Creative Commons Attribution (CC BY) license (http://creativecommons.org/licenses/by/4.0/). 